\title{
Better integrated due to a German partner? An analysis of differences in the integration of foreigners in intra- and inter-ethnic partnerships in Germany
}

\author{
NINA ROTHER \\ BUNDESAMT FÜR MigRATION UND FLÜCHTLINGE, \\ (FEDERAL OFFICE FOR MigRATION AND REFUGEES)
}

\section{Resumen}

Este estudio analiza las diferencias en la integración de extranjeros viviendo en intra e interétnicas parejas en Alemania. La teoría de la distancia social asume que los migrantes que forman parte de una pareja mixta estarán mejor integrados $\mathrm{o}$, al menos, debería darse las mejores condiciones para una integración exitosa. Esta hipótesis es analizada a través de los primeros datos del Panel Alemán de Integración. El análisis realizado condujo al resultado central de que los participantes en el curso de integración se integraban mejor cuando contaban con una pareja alemana, especialmente en cuanto a la integración cultural se refiere.

Palabras clave: parejas interétnicas, integración, migración

\begin{abstract}
This paper analyses differences in the integration of foreigners living in intraand inter-ethnic partnerships in Germany. According to social distance theory, it is assumed that migrants living in an inter-ethnic partnership should be better integrated or should have better conditions for a successful integration than foreigners living in an intra-ethnic partnership. This hypothesis is analysed by using data from the first wave of the German Integration Panel, a longitudinal survey of integration course participants. The analyses conducted led to the central result that participants of an integration course are more integrated when they have a German partner without migration background. This is especially true for their cultural integration, i.e. knowledge and usage of the German language, but also for their social and emotional integration.
\end{abstract}

Keywords: Inter-ethnic marriage, integration, migration 


\section{Introduction and research desiderata}

Interethnic marriage is often seen as a strong indicator for the integration of migrants. According to the social distance theory it is argued that the private domain in comparison to the work place, neighbourhood or circle of friends is one of the last domains in which an inter-ethnic exchange tends to happen (s. Nauck 2002a). According to this view, a migrant married to a person from the destination country without migration background can be seen as integrated. This point of view is criticised to some extent for holding some shortages as other factors might also be relevant or even more relevant for the explanation of people's marriage behaviour. It was shown that apart from individual preferences and resources, opportunities as well as structural and cultural reasons influence marriage behaviour (Haug 2004, Klein 2000, Nauck 2002b).

But nevertheless, the role of inter- and intra-ethnic marriages and partnerships remains a special one within the field of integration studies and thus deserves special attention. When addressing the role of inter- and intra-ethnic partnerships within a migrant's integration process two general directions for research appear. One is to find out which factors determine the choice of an intra- or inter-ethnic partner (e.g. Haug 2002). In this case, the partner's ethnic origin serves as dependent variable. The other research direction is to analyse the consequences of having an intra- or inter-ethnic partner on the current level of integration of a migrant and his further integration process (e.g. Rother/Nebe forthcoming). Thus, the partner's ethnic origin is (among others) included as independent variable.

This paper focuses on the latter research question and follows the common hypothesis that mirgrants living in an inter-ethnic partnership, i.e. living with a partner born in the country of residence (COR) and without migration background, should be better integrated or should have better conditions for a successful integration than foreigners living in an intra-ethnic partnership with a partner from the country of origin (COO). This should be true especially for the use of the COR-language as the partner and his family may speak exclusively in this language and thus alter the migrant's motivation to learn the COR-language (Esser 2006). But also for all other aspects of integration this hypothesis should be true. It is also assumed that the 
higher level of integration of migrants living in an inter-ethnic partnership is already true at a relatively early stage of the migrant's stay in the COR and not just after years.

Thus, this papers aims at filling some research gaps. Due to restricted available datasets most studies focus on the most common migrant nationalities in one country, the lower-skilled guest worker generation or on migrants that have lived in the destination country for a longer time (e.g. Haug 2002, Klein 2000, Schroedter 2006). When the impact of intra- and inter-ethnic partnerships on integration is analysed, researchers often choose to look at just one aspect of integration, such as knowledge of the language (e.g. Beenstock 1996, Chiswick/Miller 1992, 2007).

In contrast to the majority of studies, this research is based on a dataset that is representative for all relevant countries of origin and not only comprises older migrants but also newly arrived migrants. Integration is measured comprehensively on its four relevant subdimensions: cultural, structural, social and emotional integration (see Esser, 2001). However, as in most other papers, the analyses can only be based on data for one destination country, namely Germany, due to a restricted database.

\section{Official data on inter-ethnic marriages in Germany}

Official data on inter-ethnic marriages help to shed light on the questions from which countries migrants in Germany come from, how many persons entered into inter- and intra-ethnic marriages in the last years and how many binational or inter-ethnic couples live in Germany1.

Before presenting these data, it is necessary to make a clear differentiation between binational and inter-ethnic marriages and partnerships (see also Straßburger 2000). Whereas a marriage is classified as binational when the partners have two different nationalities, an inter-ethnic marriage consists of two partners coming from two different ethnic backgrounds, regardless of their country of birth or current citizenship. Although country of birth, citizenship and

1 An overview of the legal conditions of familiy reunification and marriage migration in Germany is given in Kreienbrink/Rühl, 2007. 
ethnic background may often be the same, they do not have to be. Thus, the two classifications differ when it comes to naturalised and second generation foreigners. Naturalised foreigners are treated the same as native persons according to the "national"-classification whereas they would belong to the category of non-natives according to the "ethnic"-classification. The same applies to second generation foreigners. This paper will apply the "ethnic"-classification as it is common within this field of research. Whenever available, detailed information on the specific migration background of intra-ethnic partnerships will be taken into account and presented.

In 2006, according to the Central Register for Foreigners (AZR), 6,7 millions foreigners were living in Germany (BAMF 2007). Thus, $8,8 \%$ of the total population do not have German citizenship. The biggest group of foreigners are Turks $(25,8 \%)$, followed by Italians $(7,9 \%)$, Serbs $(7,1 \%)$ and Poles $(5,4 \%)$. The percentages of all other nations are below $5 \%$. In addition to foreigners living in Germany, according to the population updates (Statistisches Bundesamt 2008), there are 7,8 million Germans with migration background living in Germany (either naturalised foreigners or ethnic Germans). Thus, in total about $20 \%$ of all persons living in Germany have a migration background.

In 2006, 373.681 marriages were contracted in Germany. The majority of these marriages consisted of partners both having the German citizenship (85,5\%). German males tend to be married to a foreign wife slightly more often than German females to a foreign husband $(7,2 \%$ vs. $5,3 \%)$. Foreign couples where both partners have the same foreign nationality seem to be the least frequent $(1,2 \%)$. Table 1 illustrates that German women in 2006 most often married Turkish men, followed by Italian and US-American men. German men on the other hand most often married Polish women, followed by Russian, Turkish and Thai women.

Although the presented data are very up-to-date and allow for detailed analyses concerning the nationality of the partner, they do not give information on an existing or non-existing migration background and migration experiences of both partners. What is more, the number and proportion of marriages between two partners of the same foreign nationality are substantially underestimated as these marriages are very 
often contracted in the partners' country of origin or at the respective consulate and thus are not included in these statistics.

Table 1. Marriages in 2006 - citizenships of the partner

\begin{tabular}{|l|l|l|l|}
\hline \multicolumn{2}{|l|}{ Marriage with a German wife } & \multicolumn{2}{l|}{ Marriage with a German husband } \\
\hline Citizenship of husband & Number & Citizenship of wife & Number \\
\hline Turkish & 3753 & Polish & 4319 \\
\hline Italian & 1706 & Russian & 1753 \\
\hline US-American & 1142 & Turkish & 1706 \\
\hline Moroccan & 840 & Thai & 1702 \\
\hline British & 797 & Rumanian & 1413 \\
\hline Austrian & 795 & Ukrainian & 1228 \\
\hline Serbian-Montenegrin & 765 & Italian & 945 \\
\hline Dutch & 691 & Austrian & 753 \\
\hline Polish & 617 & Croatian & 713 \\
\hline Greek & 495 & Brazilian & 681 \\
\hline
\end{tabular}

Source: Statistisches Bundesamt, unpublished data

This underestimation of foreign marriages can be avoided when using stock data from the German microcensus of 2006. The available publications based on this dataset, however, do not provide detailed information on the partners' exact citizenship but only distinguish between the three categories "German without migration background", "German with migration background" and "foreigner". In total, there are 19.385.000 married men and 19.389.000 married women currently living in Germany. Out of these, 3.535.000 married men and 3.555.000 married women have a migration background (Statistisches Bundesamt 2008).

Figures 1 for men and 2 for women present the percentages of inter- and intra-ethnic marriages for the most important groups of foreigners as well as for Germans without migration background (left column). More than $92 \%$ of all German men and women without migration background are married to a German partner who also does not have a migration background. There are relevant differences regarding the marriage patterns between different nationalities but also between men and women. Women with a citizenship from an Asian country or from Poland are more often married to a German husband 
without migration background than men with these citizenships. The opposite is true for women with a citizenship of Italy, Russia, Africa and Turkey. In comparison to all other nationalities, Turkish women are most often married to a husband from their COO (see Roloff 1998 for detailed analyses of marriage patterns in Germany).

Figure 1. Distribution of marriage patterns by nationality - Men

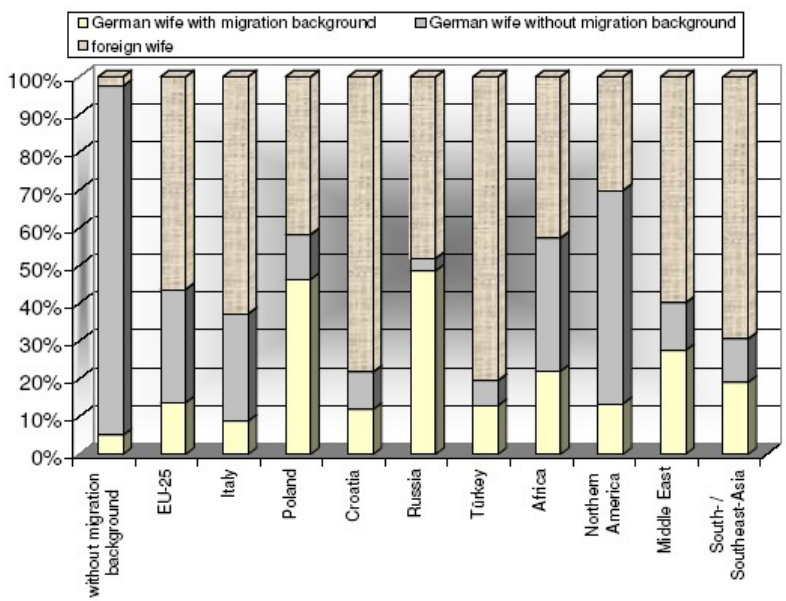

Source: German microcensus 2006, Statistisches Bundesamt

Figure 2. Distribution of marriage patterns by nationality - Women

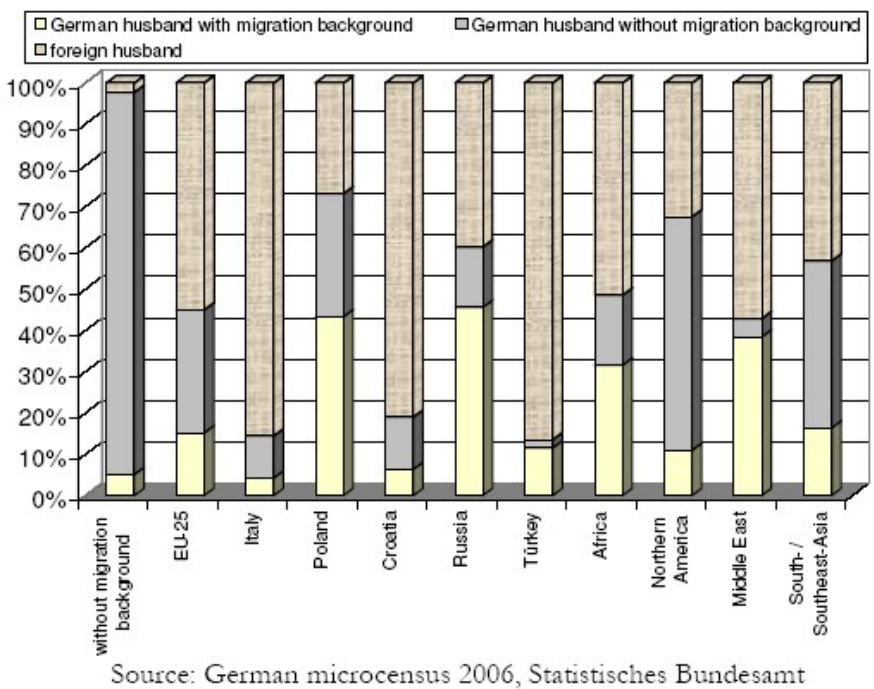


All official statistics have in common that they only refer to married couples. Information on partnerships are not available, as are data on the individual integration level. Data from surveys have significant advantages and will therefore be consulted for the following analyses.

\section{Data and Measures}

The analyses of this paper are based on the "German Integration Panel", a longitudinal survey of participants of integration courses (Rother 2008). Since 2005 a system of nationwide integration courses has been established in Germany. Whereas the participation in the course is voluntary for migrants who came to Germany before 2005, migrants who arrived after 2005 and who are not able to communicate in German on a basic level, can be obliged to take part in the courses. Integration courses consist of a language course of at least 600 hours and a so-called orientation course (45 hours) in which important information about Germany, its political system, its history and everyday life is given.

The German Integration Panel consists of three surveys of course participants plus two surveys of a control group. The first questionnaire was completed at the beginning of the course, i.e. at a very early stage of the participants' integration path and gives an overview of the integration level at the beginning of the course. The second questionnaire will be completed at the end of the integration course, the third one year after the end of the course.

The integration course participants all have a bad command of the German language in common, but regarding all other aspects diversity is the rule. Due to the mixed structure of "new" and "old" immigrants and of high- and low skilled migrants a very heterogeneous group of migrants can be assessed. The data are thus representative for all countries of origins of the course participants, and not only the most important countries of migrants to Germany (as for example the SOEP-data (Wagner et al. 2007), data from the integration survey (Haug/Diehl 2005) or data from RAM (Babka von Gostomski 2008)).

The questionnaires comprise all dimensions of integration with a special focus on the usage and knowledge of the German language and the development of these variables during and after the course. 
Questions on the socio-demographic background of the course participants also include the marital status and the partner's origin. However, no information is available on the year of arrival of the partner and other partnership-specific information (such as when and in which country both met or got married etc.).

The aim of this paper is to analyse the impact of the type of the partner's ethnic origin and of other control variables on different integration indicators. The dependent and independent variables are as follows.

\section{The dependent variables}

In order to analyse the influence of an intra- or inter-ethnic partner on the migrant's integration comprehensively, more than one dependent variable has to be chosen. Hence, the four different dimensions of integration (cultural, structural, social and emotional integration) will be represented in these analyses by at least one variable.

Within the dimension of cultural integration the person's usage of the German language within the family and among friends will be analysed. Both variables were measured on a five-point scale ranging from 1 "always" to 5 "never". In addition, the person's level of German is also taken into account. As the respondents had just started their integration course and thus should not master the German language very well, it is analysed whether the person has already reached level A1 of the Common European Framework of Reference for Languages (CEFR) (Council of Europe 2001a). The knowledge of German of the course participants was measured by using extensive self-evaluation scales following the European language portfolio (Council of Europe 2001b).

The dimension of structural integration is represented by the number of years that the migrant has already worked in Germany. Since most of the course participants came to Germany rather recently and participate in a full-time course, probably no large effects will be found.

An index measuring the intensity of social contacts to Germans was constructed in order to measure social integration. The index ranges from 1 "not at all" to 6 "daily" and comprises contacts to 
Germans within one's own family, at the workplace, in the neighbourhood and among friends.

The fourth dimension, emotional integration, is based on the measure of the person's attachment to Germany. This variable ranges from 1 "not at all attached" to 4 "very attached".

\section{Independent variables}

The ethnic origin of the partner constitutes the key independent variable. Migrants having no partner and migrants having a partner who is not living in Germany are excluded from the analyses. In addition, migrants having a partner from a third country (neither Germany nor the respondent's country of origin) were also excluded. In total, 2047 respondents were included (51,7\% of all respondents) and divided into groups according to the ethnic origin of their partner. Table 2 gives an overview of the resulting distribution. It can be seen that only $31,2 \%$ of the respondents have a German partner without migration background. The remaining $68,8 \%$ have an intra-ethnic partner with a migration background relative to the migrant's COO. Among those are partners who were also born in the respondent's $\mathrm{COO}$ and are citizens of this country $(34,4 \%)$, partners who were born in the respondent's COO but now are Germans either through naturalisation or by being ethnic Germans (31,0\%) and partners who were born in Germany but are citizens of the respondent's COO $(3,4 \%)$.

Apart from the ethnic origin of the partner, some other variables need to be included into the analyses as they might have a significant impact on either the ethnic origin of the partner or the dependent variables or both.

Table 2. Distribution of partners' ethnic backgrounds

\begin{tabular}{|l|c|c|}
\hline & Number & Percentage \\
\hline Partner is German and born in Germany & 639 & 31,2 \\
\hline Partner from COO (same migration background): & 1408 & 68,8 \\
\hline Born in COO and citizen of COO & 704 & 34,4 \\
\hline Naturalised or ethnic German & 635 & 31,0 \\
\hline 2nd generation (born in Germany) & 69 & 3,4 \\
\hline Total & 2047 & 100,0 \\
\hline
\end{tabular}


The effect of age at migration on integration, especially on language knowledge, is quite well established in the literature (e.g. Chiswick/Miller 1992, van Tubergen 2005; Esser 2006 for an overview). Migrating at a younger age might be correlated with a higher capacity and flexibility to integrate, e.g. by learning new languages or behaviour norms but also with a lower probability of having married in the COO already.

The longer a migrant's duration of stay in the COR, the more time he had for integrating, i.e. learning the language, finding friends and a job, but also the higher the chance of finding a partner from the COR.

Education is measured by the years of schooling. It is well known that a higher education facilitates the acquisition of a new language.

German knowledge at the time of migration is measured by a self-assessment question on a 5-point scale ranging from 1 "very good" to 6 "no knowledge at all". Of course it is expected that for someone who already spoke the COR's language at the time of migration it is easier to integrate, especially in terms of cultural integration, than for someone who needs to start from scratch. As normal, Gender will also be included as control variable.

Table 3. Distribution of control variables

\begin{tabular}{|c|c|c|c|c|c|c|}
\hline & \multirow{2}{*}{\begin{tabular}{|c|c|}
$\begin{array}{c}\text { Inter-ethnic } \\
\text { partnerships }\end{array}$ \\
Partner is \\
German \\
\end{tabular}} & \multicolumn{3}{|c|}{ Intra-ethnic partnerships } & \multirow[b]{2}{*}{ Total } \\
\hline & & & $\begin{array}{c}\text { Born in COO } \\
\text { and citizen of } \\
\text { COO }\end{array}$ & $\begin{array}{c}\text { Naturalised/ } \\
\text { ethnic German }\end{array}$ & $\begin{array}{c}2 \mathrm{nd} \\
\text { generation }\end{array}$ & \\
\hline Gender & $\begin{array}{c}\% \\
\text { women }\end{array}$ & $64,6 \%$ & $65,4 \%$ & $64,6 \%$ & $64,7 \%$ & $64,9 \%$ \\
\hline Age at & Mean & 29,1 & 31,0 & 31,1 & 23,9 & 30,2 \\
\hline Migration & Std.Dev. & 7,6 & 10,9 & 10,2 & 5,9 & 9,7 \\
\hline Year of & Mean & 2004,6 & 2001,5 & 2004,2 & 2003,8 & 2003,4 \\
\hline Migration & Std.Dev. & 3,9 & 6,8 & 3,8 & 4,6 & 5,3 \\
\hline Years of & Mean & 11,3 & 10,1 & 10,5 & 10,7 & 10,6 \\
\hline schooling & Std.Dev. & 3,6 & 3,4 & 2,5 & 3,2 & 3,2 \\
\hline German & Mean & 4,7 & 5,0 & 4,9 & 5,1 & 4,9 \\
\hline migration & Std.Dev. & 1,3 & 1,2 & 1,1 & 1,2 & 1,2 \\
\hline
\end{tabular}


Table 3 presents the bivariate distribution of the control variables separated by the ethnic origin of the partner. Whereas no gender differences can be found, there are significant differences regarding the age at migration. Migrants having a German partner without migration background and those having a second generation partner were younger when they migrated than migrants with a partner also born in the COO (no matter whether naturalised or not). Respondents having a partner from the COO came earlier to Germany than the other three groups (migration in 2001 in comparison to 2003/2004). They also went to school shorter than average whereas migrants with a German partner without migration background are the highest educated of all groups.

\section{Results}

As all dependent variables can be assumed to be quantitative, for each dependent variable an ANCOVA will be computed. The ethnic origin of the partner and gender are included as factors whereas all other control variables are entered as covariates due to their linearity.

\section{Cultural integration}

The use of the German language in the family is analysed as first indicator for cultural integration. Figure 3 shows the mean differences in the use of German in the family separately for the two factors ethnic origin of partner and gender. Although clear differences between men and women and migrants having a German partner without migration background and other partners can be seen, a check for their significance is necessary.

Figure 3. Use of German language in family by gender and ethnic origin of partner

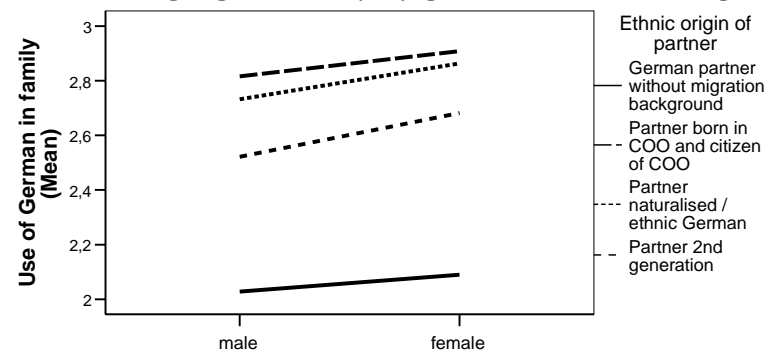

scale: 1 "always" to 4 "never" 
The results of the ANCOVA are presented in table 4. On a 95\%-level, it can be found that the partner's ethnic origin is highly significant and the most important factor, followed by the knowledge of German at the time of migration. Other significant variables are the year of migration (the longer the migrant already lives in Germany, the more he speaks German in the family) and gender (men speak more often German in the family than women). Age at migration and the educational level are less relevant and remain below significance.

When it comes to the use of German among friends, a rather similar pattern emerges (Figure 4). But apart from the ethnic origin of the partner, gender, year of migration and knowledge of German at the migration date, the age of migration and education are significant, too (Table 5).

Table 4. ANCOVA of Use of German language in family

\begin{tabular}{|l|c|c|c|c|c|}
\hline Source & $\begin{array}{c}\text { Typ III Sum } \\
\text { of Squares }\end{array}$ & $\mathrm{df}$ & $\begin{array}{c}\text { Mean } \\
\text { Square }\end{array}$ & $\mathrm{F}$ & Sig. \\
\hline Corrected Model & $243,632(\mathrm{a})$ & 11 & 22,148 & 42,057 &, 000 \\
Intercept & 4,889 & 1 & 4,889 & 9,283 &, 002 \\
Age at Migration & 1,914 & 1 & 1,914 & 3,635 &, 057 \\
Year of Migration & 5,663 & 1 & 5,663 & 10,754 &, 001 \\
Years of Schooling &, 030 & 1 &, 030 &, 057 &, 812 \\
German knowledge & 36,036 & 1 & 36,036 & 68,428 &, 000 \\
at migration & 157,614 & 3 & 52,538 & 99,764 &, 000 \\
Ethnic origin of & 2,041 & 1 & 2,041 & 3,876 &, 049 \\
partner &, 376 & 3 &, 125 &, 238 &, 870 \\
Gender & 870,509 & 1653 &, 527 & & \\
Ethnic origin of & 12589,000 & 1665 & & & \\
partner* gender & 1114,141 & 1664 & & & \\
Error & Total & & & \\
Corrected Total &
\end{tabular}

a R-Squared $=, 219$ (Adjusted R-Squared $=, 213)$ 
Figure 4. Use of German language among friends by gender and ethnic

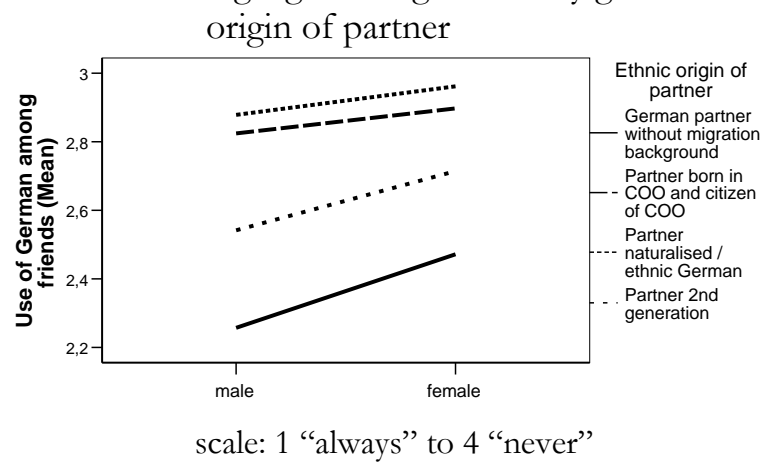

The younger the migrant at migration and the longer he went to school, the more he speaks German with his friends. Of all factors, the knowledge of German at the time of migration is the most important factor, followed by the ethnic origin of the partner. Having a German partner without migration background thus facilitates speaking German with friends. On the other hand, respondents having a partner that was born in the $\mathrm{COO}$ as well, are less likely to speak German very often among friends. However, the causal direction of this effect is not clear as it also might be the case that having friends with whom the language of communication is German helps finding a German partner. But as most respondents came to Germany rather recently and seem to have married before or directly after migration, the effect of the partner on friends can be assumed to be stronger.

Figure 5 helps to analyse the impact of the partner's ethnic origin on the respondent's current knowledge of German (at the beginning of his integration course). The vertical scale shows how many percent of the respective group have reached level A1 already at the beginning of the integration course. Again the amount is bigger among respondents with a German partner without migration background and among males. 
Table 5. ANCOVA of Use of German language among friends

\begin{tabular}{|l|c|c|c|c|c|}
\hline Source & $\begin{array}{c}\text { Type III } \\
\text { Sum of } \\
\text { Squares }\end{array}$ & df & $\begin{array}{c}\text { Mean } \\
\text { Square }\end{array}$ & F & Sig. \\
\hline Corrected Model & $144,004(\mathrm{a})$ & 11 & 13,091 & 20,787 &, 000 \\
Intercept & 2,592 & 1 & 2,592 & 4,116 &, 043 \\
Age at Migration & 7,895 & 1 & 7,895 & 12,536 &, 000 \\
Year of Migration & 3,214 & 1 & 3,214 & 5,103 &, 024 \\
Years of Schooling & 6,386 & 1 & 6,386 & 10,140 &, 001 \\
German knowledge at & 39,089 & 1 & 39,089 & 62,066 &, 000 \\
migration & 60,416 & 3 & 20,139 & 31,977 &, 000 \\
Ethnic origin of & 4,115 & 1 & 4,115 & 6,534 &, 011 \\
partner &, 817 & 3 &, 272 &, 433 &, 730 \\
Gender & 1030,974 & 1637 &, 630 & & \\
Ethnic origin of & 13581,000 & 1649 & & & \\
partner * gender & 1174,979 & 1648 & & & \\
Error & Total & & & \\
Corrected Total &
\end{tabular}

a R-Squared $=, 123$ (Adjusted R-Squared $=, 117$ )

Figure 5. Current knowledge of German language by gender and ethnic origin of partner

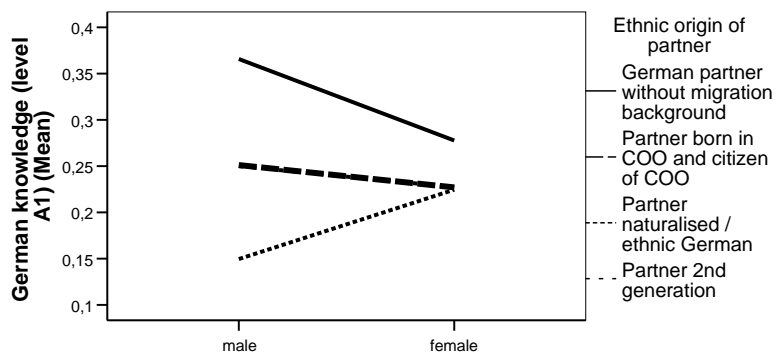

Apart from gender and age at migration, all other independent variables have a significant impact on the respondents' level of German - already at the relative beginning of the integration course in which only migrants with bad knowledge of German take part (table 6). Hence, the longer the migrant has lived in Germany or the longer he has been in school or the better has been his German when he migrated, the better is his German now. Although the effect of the partner's origin only comes in third place after the knowledge of 
German at migration and education, the effect is highly significant. In addition, there is an interaction effect of gender and the ethnic origin of the partner insofar as male course participants profit more from a German partner without migration background than women whose distribution is far more homogeneous.

Table 6. ANCOVA of knowledge of German language

\begin{tabular}{|l|c|c|c|c|c|}
\hline Source & $\begin{array}{c}\text { Type III Sum } \\
\text { of Squares }\end{array}$ & $\mathrm{df}$ & $\begin{array}{c}\text { Mean } \\
\text { Square }\end{array}$ & $\mathrm{F}$ & Sig. \\
\hline Corrected Model & $18,693(\mathrm{a})$ & 11 & 1,699 & 9,535 &, 000 \\
Intercept & 3,377 & 1 & 3,377 & 18,946 &, 000 \\
Age at Migration &, 009 & 1 &, 009 &, 052 &, 820 \\
Year of Migration & 3,250 & 1 & 3,250 & 18,237 &, 000 \\
Years of Schooling & 4,913 & 1 & 4,913 & 27,567 &, 000 \\
German knowledge at & 6,680 & 1 & 6,680 & 37,480 &, 000 \\
migration & 3,470 & 3 & 1,157 & 6,490 &, 000 \\
Ethnic origin of partner &, 006 & 1 &, 006 &, 033 &, 856 \\
Gender & 1,906 & 3 &, 635 & 3,564 &, 014 \\
Ethnic origin of partner $*$ & 294,241 & 1651 &, 178 & & \\
gender & 418,000 & 1663 & & & \\
Error & 312,934 & 1662 & & & \\
Total & Corrected Total & & & \\
\hline
\end{tabular}

a R-Squared $=, 060$ (Adjusted R-Squared $=, 053$ )

The hypothesis was that even course participants with an initial bad knowledge of German did already profit from having a German partner without migration background with regard to their cultural integration in terms of the use and knowledge of the German language. The analyses have proven that there is a strong effect of the partner's ethnic origin but that other variables such as the knowledge of German at the migration date, the year of migration, gender and education also influence the use and knowledge of German.

\section{Structural integration}

As most of the course participants came to Germany rather recently, there was little time for them to work. Thus, the overall mean of years worked in Germany is only 0.7, which is about 8 months. Figure 6 shows that males in general and respondents whose partner 
was born in the $\mathrm{COO}$ and is still a citizen of that country have worked longer in Germany than females. It can be assumend that the migration motivation of these males were mainly work related reasons whereas women came for family reunification reasons (see BAMF 2007).

Figure 6. Years worked in Germany by gender and ethnic origin of partner

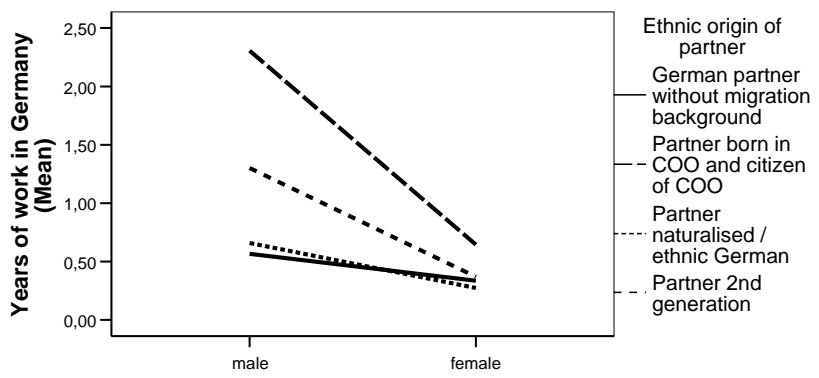

However, after controlling for all relevant variables, the effect of the partner's ethnic origin turns out to be not significant (table 7). As assumed, the year of migration is the most important factor in predicting the respondent's years worked in Germany, followed by gender. The interaction effect of gender with the partner's ethnic origin is also significant, meaning that men living in an intra-ethnic partnership with the partner also being a COO-citizen have worked longest whereas there are no differences between women. The effect of education is also significant - respondents with higher education have worked less in Germany, probably as they still spent time for their education in Germany.

Concerning the structural integration measured by years worked in Germany, no effect of the partner's ethnic origin could be found. The chosen operationalisation of structural integration, however, might not be suitable for proving a possible effect as the time spent in Germany is the restricting factor. Other indicators for structural integration such as living conditions could not yet be analysed with the existing dataset. 
Table 7. ANCOVA of years worked in Germany

\begin{tabular}{|l|c|c|c|c|c|}
\hline Source & $\begin{array}{c}\text { Type III Sum } \\
\text { of Squares }\end{array}$ & df & $\begin{array}{c}\text { Mean } \\
\text { Square }\end{array}$ & F & Sig. \\
\hline Corrected Model & $3113,154(\mathrm{a})$ & 11 & 283,014 & 97,885 &, 000 \\
Intercept & 2309,938 & 1 & $\begin{array}{c}2309,93 \\
8\end{array}$ & 798,927 &, 000 \\
Age at Migration & 7,739 & 1 & 7,739 & 2,677 &, 102 \\
Year of Migration & 2295,870 & 1 & 2295,87 & 794,062 &, 000 \\
Years of Schooling & 12,127 & 1 & 12,127 & 4,194 &, 041 \\
German knowledge at & 2,393 & 1 & 2,393 &, 828 &, 363 \\
migration & 19,581 & 3 & 6,527 & 2,257 &, 080 \\
Ethnic origin of partner & 115,903 & 1 & 115,903 & 40,087 &, 000 \\
Gender & 123,761 & 3 & 41,254 & 14,268 &, 000 \\
Ethnic origin of partner & 4761,968 & 1647 & 2,891 & & \\
$*$ gender & 8511,813 & 1659 & & & \\
Error & 7875,122 & 1658 & & & \\
Total & Corrected Total & & & \\
\hline
\end{tabular}

a R-Squared $=, 395$ (Adjusted R-Squared $=, 391$ )

\section{Social integration}

On the level of social integration, the social contacts to Germans of the course participants differ widely according to the partner's ethnic origin (figure 7). Respondents living in an inter-ethnic partnership have contacts to Germans most often while respondents living together with a naturalised foreigner of their COO or an ethnic German have least often social contacts to Germans.

Figure 7. Social contacts to Germans by gender and ethnic origin of partner

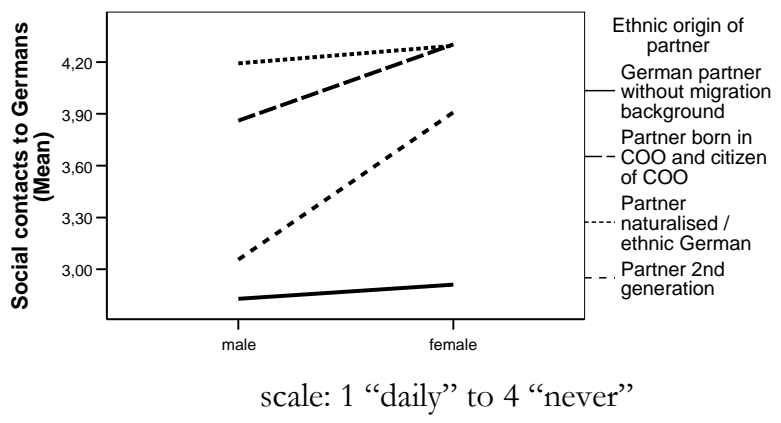


The effect of the partner's ethnic origin proves to be significant (table 8), along with the effect of the year of migration (the longer in Germany, the more social contacts to Germans), of education (the higher educated, the more social contacts) and of the level of German knowledge at the migration date (the better the German when migrating, the more social contacts). Women also have less social contacts to Germans than men, although there is no overall interaction effect of gender and the partner's ethnic origin. Also, as the effect of the ethnic origin of the partner is strongest, it can be concluded that the hypothesis of a better social integration of migrants with an interethnic partner is true.

Table 8. ANCOVA of social contacts to Germans

\begin{tabular}{|l|c|c|c|c|c|}
\hline Source & $\begin{array}{c}\text { Type III Sum } \\
\text { of Squares }\end{array}$ & df & $\begin{array}{c}\text { Mean } \\
\text { Square }\end{array}$ & F & Sig. \\
\hline Corrected Model & $665,255(\mathrm{a})$ & 11 & 60,478 & 29,869 &, 000 \\
Intercept & 50,944 & 1 & 50,944 & 25,160 &, 000 \\
Age at Migration & 3,184 & 1 & 3,184 & 1,572 &, 210 \\
Year of Migration & 54,460 & 1 & 54,460 & 26,897 &, 000 \\
Years of Schooling & 19,489 & 1 & 19,489 & 9,625 &, 002 \\
German knowledge at & 58,919 & 1 & 58,919 & 29,099 &, 000 \\
migration & 381,404 & 3 & 127,135 & 62,789 &, 000 \\
Ethnic origin of partner & 17,228 & 1 & 17,228 & 8,508 &, 004 \\
Gender & 13,163 & 3 & 4,388 & 2,167 &, 090 \\
Ethnic origin of partner * & 2751,695 & 1359 & 2,025 & & \\
gender & 23046,333 & 1371 & & & \\
Error & 3416,949 & 1370 & & & \\
Total & Corrected Total & & & \\
\hline
\end{tabular}

a R-Squared $=, 195$ (Adjusted R-Squared $=, 188$ )

\section{Emotional integration}

When it comes to the emotional integration in terms of the respondents' attachment to Germany, figure 8 depicts that again the attachment to Germany is strongest among males and respondents with a German partner without migration background. 
Figure 8. Attachment to Germany by gender and ethnic origin of partner

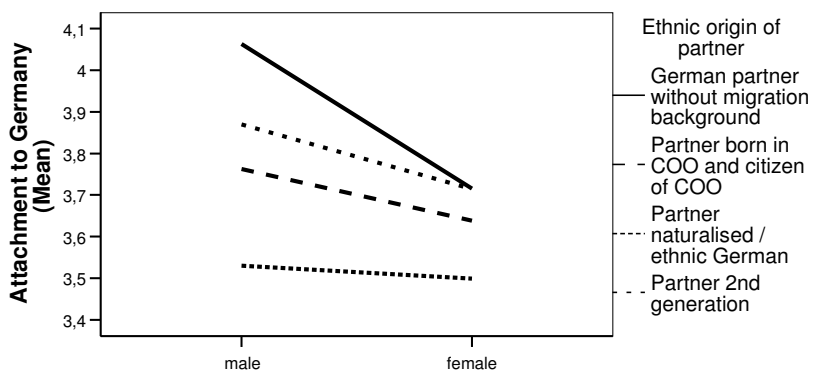

scale: 1 "not at all attached" to 4 "very attached"

Table 9. ANCOVA of attachment to Germany

\begin{tabular}{|l|c|c|c|c|c|}
\hline Source & $\begin{array}{c}\text { Type III Sum } \\
\text { of Squares }\end{array}$ & $\mathrm{df}$ & $\begin{array}{c}\text { Mean } \\
\text { Square }\end{array}$ & $\mathrm{F}$ & Sig. \\
\hline Corrected Model & $47,007(\mathrm{a})$ & 11 & 4,273 & 5,227 &, 000 \\
Intercept & 4,858 & 1 & 4,858 & 5,941 &, 015 \\
Age at Migration & 1,288 & 1 & 1,288 & 1,576 &, 210 \\
Year of Migration & 3,425 & 1 & 3,425 & 4,190 &, 041 \\
Years of Schooling &, 236 & 1 &, 236 &, 288 &, 591 \\
German knowledge at &, 781 & 1 &, 781 &, 955 &, 328 \\
migration & 26,750 & 3 & 8,917 & 10,90 &, 000 \\
Ethnic origin of partner & 4,768 & 1 & 4,768 & 5,831 &, 016 \\
Gender & 6,051 & 3 & 2,017 & 2,467 &, 061 \\
Ethnic origin of partner $*$ & 1343,299 & 1643 &, 818 & & \\
gender & 23492,000 & 1655 & & & \\
Error & 1390,306 & 1654 & & & \\
Total & Corrected Total & & & & \\
\hline
\end{tabular}

a R-Squared $=, 034$ (Adjusted R-Squared $=, 027$ )

Once again, the effect of the partner's ethnic origin on the feelings of attachment to Germany is significant and strongest of all (table 9). It is followed by gender (men feel more attached to Germany) and the year of migration (the longer in Germany, the more attached to Germany). Other variables like education, knowledge of German or age at migration do not have a significant effect on the respondents' attachment to Germany. But as the total R-square is 
rather low, it has to be supposed that other factors not included in the analysis may also play an important role. However, the ethnic background of the partner influences the course participants' emotional integration considerably.

\section{Conclusions}

The aim of this paper was to analyse if the migration background and ethnic origin of a migrant's partner influence the migrant's integration into the German society. It was assumed that migrants living in an inter-ethnic partnership with a German partner without migration background are better integrated not only in terms of a cultural integration but also concerning all other aspects of integration. It was argued that their integration should already be better at an early stage of their stay in Germany.

The data used to analyse this hypothesis stem from the German Integration Panel in which participants of integration courses filled out a questionnaire at the beginning of their course. Hence, the respondents all have in common that they came to Germany rather recently and that their command of the German language is rather poor. The sample consists of all relevant migrant groups, the results are thus not limited to specific countries of origin.

The analyses conducted led to the central result that participants of an integration course are more integrated when they have a German partner without migration background. This is especially true for their cultural integration, i.e. knowledge and usage of the German language, but also for their social and emotional integration. Regarding the structural integration in terms of the total amount of time worked in Germany, no impact of the partner's ethnic origin could be found which may also be due to the short time the course participants have been living in Germany. The results also proved that not only does the partner play an important role for the migrants' integration in general but also at the very beginning of their "integration career". The partner thus can be seen as a catalyst who will speed up the integration process now and most likely also in the future. Interestingly, and in disaccordance with what is intuitively assumed, migrants whose partner is a naturalised foreigner or ethnic German often came in last place regarding their integration level. 
Apart from the role of the partner's ethnic origin, the impact of other factors was analysed as well. It was shown that a better knowledge of German at the migration date leads to a better German now and a more intensive use of it. Another crucial factor is the length of stay in Germany which influences all aspects of integration. Education plays a role when it comes to the level of German knowledge and social contacts to Germans. Somewhat contradictive to the common assumption that women are better integrated (at least culturally), it could be demonstrated that the opposite is true. In addition, some interaction effects between the partner's origin and gender showed that men profit more from a German partner without migration background than do women. For women, there are fewer differences between women living in inter- and intra-ethnic partnerships. It has to be discussed whether this may be due to a more reserved response style of women within the survey.

It would be desirable to extend the focus of this paper to more detailed and also broader analyses in further studies. Differences between migrants from different countries should be analysed as well as developments in the integration process using longitudinal data. When available, a broader range of control variables should be included into the analyses to make sure that no factor is overlooked. The question of causality is always prevalent when analysing integration processes - path analysis and longitudinal data could help to address this problem. With the German integration panel and its three waves, it will be possible to extend the analyses as suggested. 


\section{References}

Babka von Gostomski, Christian (2008): Türkische, griechische, italienische und polnische Personen sowie Personen aus den Nachfolgestaaten des ehemaligen Jugoslawien in Deutschland: Erste Ergebnisse der Repräsentativbefragung "Ausgewählte Migrantengruppen in Deutschland 2006/2007" (RAM). Bundesamt für Migration und Flüchtlinge, Working Paper Nr. 11.

BAMF (Bundesamt für Migration und Flüchtlinge) (2007f): Migrationsbericht des Bundesamtes für Migration und Flüchtlinge im Auftrag der Bundesregierung. Nürnberg: Bundesamt für Migration und Flüchtlinge.

Beenstock, Michael (1996): The acquisition of language skills by immigrants: the case of Hebrew in Israel, International Migration, 34, 1, 3-30.

Chiswick, Barry R./Miller, Paul W. (1992): Language in the immigrant labor market. In: B. R. Chiswick (Ed.) Immigration, Language and Ethnicity: Canada and the United States. Washington: American Enterprise Institute, 229-296, 471-476.

Chiswick, Barry R./Miller, Paul W. (2007): Modeling immigrants' language skills. IZA Discussion Paper No. 2974, Bonn: Institute for the Study of Labor (IZA).

Council of Europe (2001a): The Common European Framework in its political and educational context. <http://www.coe.int/T/DG4/Linguistic/Source/Framework _EN.pdf> Date: 28.04.2008.

Council of Europe (2001b): European Language Portfolio. $<$ www.coe.int/T/DG4/Portfolio/?L=E\&M=/main_pages/introducti on.html> Date: 28.04.2008.

Esser, Hartmut (2001): Integration und ethnische Schichtung. Mannheim: MZES Arbeitsbericht Nr. 40.

Esser, Hartmut (2006): Sprache und Integration. Die sozialen Bedingungen und Folgen des Spracherwerbs von Migranten. Frankfurt: Campus.

Haug, Sonja/Diehl, Claudia (2005): Aspekte der Integration. Eingliederungsmuster und Lebenssituation italienisch- und türkischstämmiger junger Erwachsener in Deutschland. Schriftenreihe des Bundesinstituts für Bevölkerungsforschung, Band 35. Wiesbaden: VS. 
Haug, Sonja (2002): Familie, soziales Kapital und soziale Integration. Zur Erklärung ethnischer Unterschiede in Partnerwabl und generativem Verbalten bei jungen Erwachsenen deutscher, italienischer und türkischer Abstammung. In: Zeitschrift für Bevölkerungswissenschaft 27,4: 393-425.

Haug, Sonja (2004): Binationale Ehen und interethnische Partnerschaften in Deutschland - Datenlage und Erklärungsfaktoren. In: Zeitschrift für Familienforschung 16/3, S. 305- 329.

Klein, Thomas (2000): Binationale Partnerwabl - Theoretische und empirische Analysen zur famialen Integration von Ausländern in die Bundesrepublik. In: Sachverständigenrat zum 6. Familienbericht (Hrsg.): Familien ausländischer Herkunft in Deutschland. Band 1, Opladen: Leske + Budrich: 303-346.

Kreienbrink, Axel/Rühl, Stefan (2007): Family Reunification in Germany. Small Scale Study IV in the Framework of the European Migration Network. Nürnberg: Bundesamt für Migration und Flüchtlinge, Working Paper Nr. 10.

Nauck, Bernhard (2002a): Solidarpotenæiale von Migrantenfamilien <http://library.fes.de/fulltext/asfo/01389toc.htm> Date: 28.04.2008.

Nauck, Bernhard (2002b): Dreißig Jabre Migrantenfamilien in der Bundesrepublik. Familiärer Wandel zwischen Situationsanpassung, Akkulturation, Segregation und Remigration. In: Nave-Herz, Rosemarie (Hrsg.) Kontinuität und Wandel der Familie in der BRD. Stuttgart: Lucius \& Lucius: 315-339.

Roloff, Juliane (1998): Eheschließungen und Ehescheidungen von und mit Ausländern in Deutschland. In: Zeitschrift für Bevölkerungswissenschaft 23,3: 319-334.

Rother, Nina (2008): Das Integrationspanel: Ergebnisse zur Integration von Teilnehmern zu Beginn ibres Integrationskurses. Nürnberg: Bundesamt für Migration und Flüchtlinge, Working Paper Nr. 14.

Rother, Nina/Nebe, Tina. (forthcoming). More mobile, more European? Free movement and EU identity. In E. Recchi \& A. Favell (eds.) Pioneers of European Integration. The Spatial and Social Mobility of Intra-EU Migrants. 
Schroedter, Julia (2006): Binationale Ehen in Deutschland. In: Wirtschaft und Statistik, 4, 419-431.

Statistisches Bundesamt (2008): Bevölkerung und Erwerbstätigkeit. Bevölkerung mit Migrationshintergrund - Ergebnisse des Mikrozensus 2006. Fachserie 1 Reihe 2.2. Wiesbaden: Statistisches Bundesamt.

Straßburger, Gabi (2000): Das Heiratsverhalten von Personen ausländischer Nationalität oder Herkunft in Deutschland. In: Sachverständigenrat zum 6. Familienbericht (Hrsg.): Familien ausländischer Herkunft in Deutschland. Band 1, Opladen: Leske + Budrich: 9-48.

Van Tubergen, Frank/Kalmijn, Matthijs (2005): Destination-language proficiency in cross-national perspective: a study of immigrant groups in nine Western countries. In: American Journal of Sociology, 110, 5, 1412-1457.

Wagner, Gert G./Frick, Joachim R./Schupp, Jürgen (2007): The German Socio-Economic Panel Study (SOEP) - Scope, Evolution and Enhancement. In: Schmollers Jahrbuch, Journal of Applied Social Studies 127, 1: 139-169. 